\title{
Konstrukcja liberalnego państwa prawa a zakres kompetencji ministrów spraw wewnętrznych w Polsce międzywojennej
}

\section{Struktur des liberalen Rechtsstaates und Kompetenzenbereich der Innlandsminister in Polen zwischen den Kriegen}

1. Model ustrojowy II Rzeczypospolitej a konstrukcja państwa prawa. 2. System demokracji parlamentarnej a organizacja i funkcjonowanie administracji publicznej. 3. Kształtowanie się zakresu kompetencji ministrów spraw wewnętrznych $w$ ramach zadań administracji publicznej w latach 1918-1926. 4. Zamach majowy a sprawa utrzymania modelu państwa liberalnego. 5. System autorytarny a organizacja i funkcjonowanie administracji publicznej. 6. Ksztaltowanie się zakresu kompetencji ministrów spraw wewnętrznych w ramach zadań administracji publicznej w latach 1926-1939. 7. Zakres zadań ministrów spraw wewnętrznych na gruncie ustawodawstwa odziedziczonego po państwach zaborczych i okupacyjnych oraz struktura resortu spraw wewnętrznych. 8. Podsumowanie.

1. Gesellschaftsordnung der II. Polnischen Republik und das System des Rechtsstaates. 2. Parlamentarische Demokratie einerseits und Organisation, und Funktionierung der öffentlichen Verwaltung andererseits. 3. Bildung der Kompetenzbereiches der Innlandsminister in Rahmen der öfentlichen Verwaltungsaufgaben (1918-1926). 4. Maiputsch und das Problem der Kontinuation des liberalen Staatsmodells. 5. Autoritärsystem, Organisation und Funktionierung der öffentlichen Verwaltung. 6. Bildung der Kompetenzbereiches der Innlandsminister im Rahmen der öffentlichen Verwaltungsaufgaben (1926-1939). 7. Aufgaben des Innlandministeriums im polnischen Gesetzgebung, nach den drei Teilungsstaaten Polens geerbt. 8. Schlussfolgerungen.

1. Rolę i miejsce administracji publicznej ${ }^{1}$, a w szczególności ministrów spraw wewnętrznych jako szefów resortu spraw wewnętrznych ${ }^{2}$ w Rzeczypospolitej Polskiej w latach 1918-1939, można scharakteryzować, gdy ustali siẹ, po

${ }^{1}$ Kształtowanie się administracji publicznej ściśle łączy się z powstaniem modelu państwa prawa. Jest ona przeciwstawiana administracji państwowej charakterystycznej dla państwa totalitarnego. Obecnie w literaturze przedmiotu można spotkać, jednakże zastępczo, określenie administracji publicznej jako administracji państwowej. Chodzi tu o administracje państwowz państwa prawnego. Por.: H. I zdebs ki, M. Kules za, Administracja publiczna. Zagadnienia ogólne, Warszawa 1999; Z. Le ońs ki, Nauka administracji, Warszawa 2000.

${ }^{2}$ Pomijamy tu kompetencje ministrów spraw wewnętrznych wynikające $\mathrm{z}$ ich członkostwa w Radzie Ministrów. Por. W. Komarnicki, Polskie prawo polityczne (geneza $i$ system), 
pierwsze - model ustrojowy państwa ${ }^{3}$, po drugie - system polityczny w państwie ${ }^{4}$, i po trzecie - ogólne zasady organizacji i funkcjonowania administracji publicznej $w$ tymże państwie.

Otóż, już w pierwszych latach Polski Niepodległej (1918-1921) w sposób zasadniczy ukształtował się jej model ustrojowy ${ }^{5}$. Rzeczpospolita odrodziła się jako republika konstytucyjna. Konstrukcja ustroju politycznego oparta została na wypracowanym $\mathrm{w}$ XIX stuleciu w Europie modelu państwa liberalnego, którego pragmatyczną kodyfikacją była konstrukcja państwa prawnego (Rechtsstaat) określanego również jako państwo praworządne lub państwo prawa ${ }^{6}$.

Konstrukcja państwa prawnego pojawiła się w pierwszej połowie XIX w. Jego głównym teoretykiem byl wybitny niemiecki prawnik Robert von Mohl $^{7}$. Koncepcja ta była orężem intelektualnym liberałów niemieckich, a także europejskich $w$ walce $z$ konserwatystami $i$ monarchistami o nowy ustrój społeczny i polityczny. Państwo prawne stanowiło więc przeciwieństwo konstrukcji państwa policyjnego. Po długoletnich zmaganiach, w drugiej połowie wieku XIX w poszczególnych państwach europejskich poczęli zwyciężać liberałowie i ich wizja ustroju państwowego. Konstrukcja państwa prawnego stawała się rzeczywistością ustrojowoprawną w Cesarstwie Niemieckim, Monarchii Austro-Węgierskiej, Republice Francuskiej, Królestwie Wielkiej Brytanii, państwach skandynawskich czy Królestwie Włoskim.

Warszawa 1922, s. 292-293; A. G u l c zy ń sk i, Ministerstwo bylej Dzielnicy Pruskiej (1919-1922), Poznań 1995, s. 37-38.

${ }^{3}$ Jedna $z$ wielu definicji państwa mówi, iż państwo jest organizacją, która ma statut organizacyjny, czyli konstytucję. Konstytucja jako najważniejszy akt prawny w państwie reguluje przede wszystkim ustrój państwa, a ponadto podstawowe prawa i obowiązki obywateli oraz podstawy porządku gospodarczego $w$ państwie, $w$ tym przede wszystkim stosunki własnościowe. Ustrój państwa, czyli urządzenie panstwa, określany jest przez następujące elementy: wskazanie suwerena, czyli podmiotu, od którego wywodzi się wszelka władza w państwie; wskazanie organów państwa, ich uprawnień oraz ich obowiązków; określenie relacji między organami państwa. Kompendium wiedzy o spoleczeństwie, państwie i prawie, red. S. Wronkowska, M. Zmierczak, PWN, Warszawa-Poznań 1995, s. 58.

${ }^{4}$ Jest wiele definicji systemu politycznego. Najogólniej można je podzielić na definicje instytucjonalne (strukturalne), behawiorystyczno-funkcjonalne i systemowe. Przykładowo, teoria instytucjonalna mówi, iż: System polityczny to ogól organów państwowych, a także partii politycznych, organizacji spolecznych oraz grup nieformalnych, uczestniczqcych $w$ dzialaniach politycznych $w$ ramach danego państwa, jak również ich wzajemne stosunki, tworzqce funkcjonalnq calość; M. Chmaj, M. Ż migrodzk i, Wprowadzenie do teorii polityki, Wyd. UMCS, Lublin 1996, s. 180 i 185.

${ }^{5}$ S. Krukowski, Mala Konstytucja $z 1919$ r., Konstytucja Rzeczypospolitej Polskiej z 1921 r., [w:] Konstytucje Polski. Studia monograficzne z dziejów polskiego konstytucjonalizmu, t. 2, red. M. Kallas, Warszawa 1990 , s. 7 i n., s. 19 i n.

${ }^{6} \mathrm{~J}$. M a 1 ec, D. Malec, Historia administracji $i$ myśli administracyjnej, Kraków 2000, s. 117 i n.

${ }^{7}$ H. I z d e b ski, Historia administracji, Warszawa 1997, s. 102. 
Wiele elementów państwa prawnego znajdziemy nawet w ustroju Rosji, będących wynikiem reform cara Aleksandra II $^{8}$. Wprowadzenie w życie w drugiej polowie XIX w. zasad państwa prawnego było praktyczną realizacją programu politycznego europejskich liberałów, dostosowanego do realiów spoleczno-politycznych dominujących w owym czasie w monarchiach konstytucyjnych, a po I wojnie światowej model państwa prawnego został dostosowany do panujących w większości państw europejskich realiów politycznych republik konstytucyjnych ${ }^{9}$.

Do cech konstytutywnych państwa liberalnego uksztaltowanego w drugiej polowie XIX w. zaliczamy: konstytucjonalizm, prawa obywatelskie ze szczególnym uwzględnieniem równości wszystkich obywateli wobec prawa (jednak często bez równości w dziedzinie prawa wyborczego), nietykalność mieszkania i własności prywatnej; nadto wolności obywatelskie, takie jak: wolność myśli, wyznania i sumienia, i dalej: wolność słowa, prasy, koalicji, wolność narodowościowa; zasada odpowiedzialności ministrów przed parlamentem. Cechą tegoż państwa były również takie instytucje polityczno-administracyjne, jak: administracja rządowa, samorząd terytorialny i sądownictwo administracyjne ${ }^{10}$.

Konstrukcja państwa prawnego łączyła się zarazem $\mathrm{z}$ dominującą w nauce prawa drugiej polowy XIX w. doktryną pozytywizmu prawniczego. Doktryna ta mówiła, iż organy państwa, a szczególnie administracja może tylko i wylącznie działać $w$ ramach prawa lub na podstawie przepisów prawa. Natomiast jedynym prawodawcą jest państwo, zaś zadaniem prawników jest tylko interpretować i stosować normy prawa obowiązującego. Zgodnie z założeniem państwa prawnego, akty prawne miały znajdować się $w$ porządku hierarchicznym: na szczycie ich piramidy miała stać konstytucja, niżej ustawy zwykłe, dalej rozporządzenia i inne akty normatywne administracji, wreszcie na samym dole - indywidualne decyzje administracyjne i wyroki sądowe. Akty niższego szczebla powinny być zgodne z aktami wyższego szczebla i w zasadzie mogly być wydawane tylko na ich podstawie ${ }^{11}$. Na początku XX w. konstrukcja państwa prawnego coraz mniej była programem ustrojowo-politycznym, stając się raczej usystematyzowaną rzeczywistością polityczno-administracyjną $\mathrm{w}$ poszczególnych państwach europejskich, a więc i na ziemiach polskich, przede wszystkim w zaborze pruskim i austriackim.

Koncepcja państwa prawa ugruntowała poddanie administracji publicznej „rządom prawa”. W konsekwencji, z przepisów regulujących organizację i działalność administracji uczyniła prawo administracyjne. Odtąd też normy

8 J. M alec, D. Malec, Historia administracji $i$ myśli.., s. 132 i n.

9 Prawo administracyjne..., s. 10.

${ }_{10}$ H. I zdebski, Historia..., s. 102; E. B orkowska-Bagieńska, K. Kra sowski, B. Lesiński, J. Wala chowicz, Historia państwa i prawa Polski. Zarys wykladu, Poznań 1994 , s. $225-226$.

${ }^{11}$ H. I zde b sk i, Historia...., s. 91, 102-103; Prawo administracyjne..., s. 10

${ }^{16}$ Bibliot. Sejm. Sprawozd. sten. z 167. posiedzenia Sejmu Ustawod. z 24 IX 1920 r., pag. 19

${ }_{17}$ Bibliot. Sejm. Sprawozd. sten. z 333. posiedzenia Sejmu Ustawod. z 3 VIII 1922 r., pag. 11.

18 A. A jnenkiel, Historia administracji w Polsce. Zarys historyczny, Warszawa 1977, s. 55-58; D. M a le c, J. M a le c, Historia administracji nowożytnej, Kraków 1997, s. 107 i n.

${ }^{19}$ H. I zdebski, Historia..., s. 61. 
odnoszące się do administracji nabrały charakteru dwustronnie obowiązującego: tak więc obowiązywały nie tylko obywateli, ale $\mathrm{i}$ aparat administracyjny. Administracja nie mogla już zatem ingerować $w$ sferę praw obywateli w dowolnych przypadkach $\mathrm{i}$ w dowolnych formach - tak jak to się działo

stawało się, iż organy administracyjne nie mogą służyć jednej partii, a pracownicy administracji nie mogą utożsamiać się $\mathrm{w}$ sposób formalny z żadną partią. Administracja jako taka i zatrudnieni w niej pracownicy winni służyć jedynie państwu i realizować zadania polityczno-administracyjne ustalone dla niej przez aktualnie rządzący układ polityczny w państwie. Zadania te winny być zawarte w określonych aktach prawnych i w wydanych na ich podstawie zarządzeniach szczegółowych. H. Izdebski pisze, iż w czasie XIX w. utrwaliła się zasada apolityczności funkcjonariuszy państwowych. $Z$ zasady tej wynikal zakaz uprawiania dzialalności politycznej $i$ przynależności do partii politycznych. Zasada apolityczności miala jednak $w$ dużej mierze charakter formalny, bowiem nie brala pod uwage ogólnego uwiklania funkcjonariuszy, zwlaszcza wyższych, w polityke ${ }^{20}$. W konsekwencji pojęcie apolityczności aparatu administracji publicznej należałoby zastąpić pojęciem apartyjności aparatu administracji publicznej. Właśnie w Polsce w latach 1918-1926 zasada ta była chyba w stopniu najbardziej szerokim stosowana ${ }^{21}$.

3. Administracja państwowa, funkcjonując w wyżej nakreślonych ramach ustrojowoprawnych i politycznych, realizowała swoje zadania przez grupy organów administracyjnych działających na zwartych kompleksach społecznych. Jedną $\mathrm{z}$ tych grup organów był resort spraw wewnętrznych; na jej czele stał Minister Spraw Wewnętrznych. Oficjalnie jego urząd został powołany już w czasie I wojny światowej, 7 grudnia 1917 r. W tym dniu został utworzony pierwszy rząd polski pod egidą Rady Regencyjnej. Na jego czele stanął Jan Kucharzewski, a szefem resortu spraw wewnętrznych zostal Jan Stecki ${ }^{22}$. Natomiast 1 lutego $1918 \mathrm{r}$. ogłoszono dekret Rady Regencyjnej z dnia 3 stycznia 1918 r. o tymczasowej organizacji wladz naczelnych $w$ Królestwie Polskim $^{23}$. Dekret ten ustalił po raz pierwszy stanowisko prawnopaństwowe ministrów, określił ich kompetencje, a podlegające dotąd ministrom departamenty, jako ich aparaty pomocnicze (urzędy organu) przekształcił w ministerstwa. Artykuł 24 tegoż dekretu określal po raz pierwszy kompetencje Ministra Spraw Wewnętrznych, natomiast art. 38 przekształcal Departament Spraw Wewnętrznych w Ministerstwo Spraw Wewnętrznych. Tak więc dekret z 3 stycznia 1918 r. byl konstytucja polskich organów emancypacyjnych $w$ czasie okupacji, przejęta następnie przez nowo powstale państwo polskie ${ }^{24}$.

20 Ibidem, s. 155 .

${ }^{21}$ W. Kozyra, Urząd Wojewódzki w Lublinie w latach 1919-1939, Lublin 1999, s. 157; por. S. Kutrzeba, Polska odrodzona, Kraków 1988.

22 J. P a jewski, Odbudowa państwa polskiego 1914-1918, Warszawa 1980, s. 212-213.

${ }^{23}$ Dziennik Praw Królestwa Polskiego [dalej: DzPrKP] nr 1, poz. 1.

${ }^{24} \mathrm{R}$. H a u s ner, Pierwsze dwudziestolecie administracji spraw wewnetrznych, Warszawa 1939, s. 4; por. D. Gó r e c ki, Powstanie wladz naczelnych w odradzajqcej sie Polsce 1914-1919, Łódź 1984. 
Okres I wojny światowej należy jednak traktować jako czas kładzenia podwalin pod organizacje i funkcjonowanie polskiego resortu spraw wewnętrznych. Historię tegoż resortu i dzieje ministrów spraw wewnętrznych w Polsce Niepodległej należy datować od 11 listopada 1918 r., a za pierwszego ministra spraw wewnętrznych w II Rzeczypospolitej - uznać Stanisława Thugutta powołanego na ten urząd 17 listopada $1918 \mathrm{r}^{25}$ Wchodził on w skład rządu ludowego Jędrzeja Moraczewskiego powołanego przez Józefa Piłsudskiego.

Urząd Ministra Spraw Wewnętrznych posiadał bardzo szeroki zakres zadań. $\mathrm{Z}$ tego też powodu, $\mathrm{z}$ podległej mu struktury wyodrębniały się często nowe piony administracji państwowej, zaś kompetencje ministrów spraw wewnętrznych kształtowały się na tzw. zasadzie negatywnej lub klauzuli generalnej, a pozostałych ministerstw - na zasadzie pozytywnej lub klauzuli enumeratywnej. Otóż już dekret Rady Regencyjnej z 3 stycznia 1918 r. mówil, iż na kompetencje Ministra Spraw Wewnętrznych - poza sprawami szczególowo wyliczonymi - składają się sprawy natury wewnętrznej dla innych ministerstw nie zastrzeżone ${ }^{26}$. Odpowiednikiem tego przepisu był art. 67 rozp. Prezydenta RP z 19 stycznia $1928 \mathrm{r}^{27}$ stanowiący, że do zakresu działania starosty należą sprawy, w których nie da się ustalić właściwości rzeczowej innej władzy, albo gdy obowiązujące przepisy przewidują właściwość wladz już nie istniejących, a nie można ustalić, kto przejął ich uprawnienia. Innymi slowy, na uprawnienia Ministra Spraw Wewnętrznych składały się przede wszystkim sprawy dotyczące bezpieczeństwa i spokoju publicznego oraz te wszystkie, które nie wchodzily w skład wlaściwości innych resortów. Przyjęcie takiej właśnie klauzuli generalnej spowodowało znaczną płynność zakresu zadań resortu na przestrzeni dwudziestolecia międzywojennego.

Dekret z 3 stycznia 1918 r. powoływał do życia dziesięć resortów; były to ministerstwa: Sprawiedliwości; Skarbu; Oświaty i Wyznań; Rolnictwa i Dóbr Państwowych; Przemysłu i Handlu; Opieki Społecznej i Ochrony Pracy; Aprowizacji; Spraw Wewnętrznych, a także pozostawione: Departament Spraw Politycznych - jako surogat resortu spraw zagranicznych, oraz Komisja Wojskowa - jako quasi-ministerstwo spraw wojskowych ${ }^{28}$. Już jednak w połowie 1919 r. bylo 17 resortów i szereg urzędów centralnych, $\mathrm{w}$ większości na prawach ministerstw; były to $\mathrm{m}$. in. Główny Urząd Likwidacyjny, Główny Urząd Statystyczny i Główny Urząd Ziemski. Ta liczba resortów w 1923 r. spadła do 12, a od 1932 r. ustabilizowała się na

\footnotetext{
${ }^{25}$ Monitor Polski z 18 XI 1918 r., nr 206.

${ }^{26}$ DzPrKP, nr 1, poz. 1, art. 24.

${ }^{27}$ Dziennik Ustaw Rzeczypospolitej Polskiej [dalej: DzURP] z 1936 r., nr 80, poz. 555

${ }^{28}$ DzPrKP, nr 1, poz. 1.
} 
poziomie $11^{29}$. Znaczna czẹśc kompetencji likwidowanych resortów przechodziła w gestię MSW.

Dekret z 3 stycznia 1918 r. po raz pierwszy określał zakres właściwości Ministra Spraw Wewnętrznych. Artykul 24 głosił: Do Ministra Spraw Wewnętrznych należa: przygotowanie, a nastepnie objecie $i$ prowadzenie wszelkich spraw wchodzacych $w$ zakres ogólnego zarzqdu krajowego i prowadzenie dozoru nad samorzadem miejscowym, policji wszelkiego rodzaju, slużby zdrowia, budownictwa $i$ odbudowy kraju, koncesjonowanie $i$ zarzqd sil wodnych, zawiadywanie dróg ladowych, poczt, telegrafów i telefonów oraz wszelkich $w$ ogóle środków komunikacji, nie pozostajacych pod zarządem wojskowym albo Ministra Przemyslu i Handlu, sprawy naturalizacji państwowej, statystyki ogólnej, zarzq̨du ubezpieczeń państwowych, nadzór nad prasa, wreszcie sprawy natury wewnętrznej, dla innych ministerstw nie zastrzeżone $e^{30}$. W przedstawionym powyżej artykule zostały więc określone najbardziej ogólne kompetencje MSW.

Do końca II Rzeczypospolitej do zakresu kompetencji Ministra Spraw Wewnętrznych należały: 1) prowadzenie wszelkich spraw ogólnego zarządu krajowego, 2) dozór nad samorządem miejscowym, 3) policja wszelkiego rodzaju, 4) budownictwo, 5) naturalizacja państwowa, 6) statystyka ogólna, 7) nadzór nad prasą, 8) sprawy natury wewnętrznej dla innych ministerstw nie zastrzeżone ${ }^{31}$. Zakres ten jednakże obejmowal wiele spraw, które przeszły do innych resortów i w ostatnich latach II Rzeczypospolitej do działań MSW już nie należały. Wcześnie, bo dekretem Rady Regencyjnej z 4 kwietnia $1918 \mathrm{r}$. ministrowi odebrano sprawy służby zdrowia i przekazano nowo utworzonemu resortowi zdrowia publicznego, opieki społecznej i ochrony pracy $^{32}$. Następnie wyłączono wszystkie sprawy statystyki ogólnej. Reskryptem Rady Regencyjnej z 19 lipca 1918 r. został zorganizowany Główny Urząd Statystyczny przy Prezydencie Ministrów. Dalsze poważne zmiany nastąpiły jesienią 1918 r.: 25 października istniejący przy urzędzie Ministra Spraw Wewnętrznych, Urząd Aprowizacji przeksztalcono w Ministerstwo Aprowizacji ${ }^{33}$. 31 grudnia tegoż roku dekretem Tymczasowego Naczelnika Państwa wyłączono z uprawnień Ministra Spraw Wewnętrznych zagadnienia weterynaryjne i przekazano je Ministrowi Rolnictwa i Dóbr Państwowych ${ }^{34}$.

Na początku 1919 r. utworzono nowy resort Ministra Robót Publicznych; w konsekwencji 16 stycznia 1919 r. wyłączono cały zakres administracji

\footnotetext{
${ }^{29}$ R. H a u n ner, Pierwsze dwudziestolecie..., s. 12.

${ }^{30}$ DzPrKP, nr 1, poz. 1, art. 24.

${ }^{31} \mathrm{R}$. H a u s ner, Pierwsze dwudziestolecie..., s. 14.

${ }^{32}$ DzPrKP, nr 5, poz. 8.

${ }^{33}$ Dziennik Praw Państwa Polskiego [dalej: DzPrPP], nr 14, poz. 30.

${ }^{34}$ DzPrPP, nr 5, poz. 92.
} 
technicznej z gestii resortu spraw wewnętrznych ${ }^{35}$. W lutym $1919 \mathrm{r}$. powolano kolejnego ministra - Poczt i Telegramów; stąd też kolejne wyłączenie kompetencyjne $\mathrm{z}$ zakresu uprawnień Ministra Spraw Wewnętrznych ${ }^{36}$.

Po uchwaleniu Konstytucji Marcowej zaistniała konstytucyjna podstawa prawna do uporządkowania podstawowego zakresu uprawnień poszczególnych ministrów, w tym i Ministra Spraw Wewnętrznych. Podstawa tą był art. 63 Konstytucji przewidujący wydanie ustawy, która określałaby liczbe, zakres dzialania $i$ wzajemny stosunek ministró $w^{37}$. Niestety ustawa taka nigdy nie weszła w życie.

Rząd Leopolda Skulskiego, na podstawie uchwały Rady Ministrów z 7 czerwca 1920 r., złożył jedynie sejmowi projekt ustawy o zakresie działania władz naczelnych ${ }^{38}$. Projekt ten nigdy nie zostal przez sejm rozpatrzony. Mimo to warto go pokrótce omówić, gdyż faktycznie określał zasadniczy zrąb uprawnień ministra jako kierownika resortu spraw wewnętrznych w międzywojennej Polsce. W projekcie tym, w art. 4 określano jego podstawowe kompetencje; były to: sprawy wchodzące w zakres ogólnej administracji kraju, o ile nie były zastrzeżone innym ministrom lub urzędom centralnym; następnie kwestie utrzymania porządku publicznego i bezpieczeństwa oraz samorządu terytorialnego. W szczególności, w zakres kompetencji szefa resortu spraw wewnętrznych wchodziły zagadnienia:

1. W zakresie spraw dotyczących administracji ogólnej: a) przeprowadzanie wyborów do sejmu i senatu; b) sprawy podziału administracyjnego kraju, regulacje granic województw, powiatów i gmin, zmiany nazw miejscowości oraz przedkładanie wniosków w przedmiocie podnoszenia miejscowości do rzędu miast; c) administracja stosunków osobistych, sprawy obywatelstwa (przynależności państwowej i gminnej), sprawy metrykalne i zmiany nazwisk; d) ewidencja ludności indywidualna i zbiorowa, księgi ludności; e) ustanawianie i wykonanie zarządu przymusowego zakladów i urządzeń użyteczności publicznej, orzekanie o wywłaszczeniu w obrębie swojego zakresu działania; f) załatwianie spraw związanych z obronnością kraju, a mianowicie: mobilizacją, demobilizacją, osobistymi i rzeczowymi świadczeniami wojskowymi obywateli oraz innymi świadczeniami administracyjnymi na rzecz wojska.

2. W zakresie spraw dotyczących utrzymania bezpieczeństwa i porządku publicznego: a) czuwanie nad stanem bezpieczeństwa oraz zapobieganie wewnętrznym niepokojom; b) nadzór nad ruchem ludności, kontrole, zezwolenia na zamieszkiwanie, wydalanie cudzoziemców oraz kwestie meldunkowe i paszportowe; c) sprawy zgromadzeń i wieców; d) kontrole ruchu

${ }^{35}$ DzPrPP, nr 8, poz. 118.

${ }^{36}$ DzPrPP, nr 13, poz. 142.

${ }^{37}$ Ustawa z 17 marca 1921 r. Konstytucja Rzeczypospolitej Polskiej, [w:] M. A da m cz y k, S. P a stuszka, Konstytucje polskie w rozwoju dziejowym, Warszawa 1985, s. 217-249.

${ }^{38}$ R. H a u sner, Pierwsze dwudziestolecie..., s. 15; Druk Sejmowy nr 1893. 
granicznego i czuwanie nad calością granic państwa; e) areszty policyjne; f) zagadnienia ruchu publicznego; g) organizacja i kierownictwo policji; h) nadzór nad obrotem niebezpiecznymi materiałami, sprawy broni, amunicji i materiałów wybuchowych; i) nadzór nad stowarzyszeniami, to jest: legalizacja i rejestracja stowarzyszeń i związków nie mających na celu przychodów materialnych, zatwierdzanie statutów stowarzyszeń spożywczych; j) nadzór nad prasą, drukarniami oraz składami druków; k) koncesjonowanie i nadzór nad teatrami, kinami i widowiskami; 1) udzielanie koncesji na przedsiębiorstwa komisowe i lombardy oraz $\mathrm{m}$ ) wykonywanie wyjątkowych pelnomocnictw w zakresie bezpieczeństwa i porządku publicznego.

3. W zakresie spraw samorządowych: a) nadzór nad organizacją i działalnością organów komunalnych; b) sprawy finansów komunalnych, banku komunalnego oraz komunalnych kas oszczędnościowych; c) działalność instrukcyjna.

4. Wspóldziałanie $\mathrm{z}$ innymi ministerstwami $\mathrm{w}$ przypadkach przewidzianych ustawą oraz $w$ innych zagadnieniach dotyczących zakresu działania ministra spraw wewnętrznych.

Projekt ten nie wszedł $w$ życie, a zakres ustawowych uprawnień ministra spraw wewnętrznych nadal ulegał częstym zmianom. Związane to bylo $z$ działalnością komisji usprawniającej $i$ reorganizującej administrację publiczną, a zwłaszcza administracje centralnąa ${ }^{39}$. Tak więc $w$ związku $z$ wejściem w życie ustawy o przymusie ubezpieczenia od ognia $z$ dnia 23 czerwca 1921 r. obszar spraw związanych z zarządem ubezpieczeń państwowych przeszedl do kompetencji ministra skarbu ${ }^{40}$. Natomiast ustawa z 17 grudnia 1921 r. ponownie przekazała $w$ gestię ministra spraw wewnętrznych kompleks spraw aprowizacyjnych, gdyż stanowisko Ministra Aprowizacji zostało skasowane $e^{41}$. Do resortu spraw wewnętrznych ponownie powrócil Główny Urząd Statystyczny; stało się to 1 czerwca $1923 \mathrm{r}^{42}$ I kolejna duża zmiana w ustawowych uprawnieniach Ministra Spraw Wewnętrznych: ustawą z 28 listopada 1923 r. zniesiono resort zdrowia publicznego, a rozporządzenie Prezydenta RP z 18 stycznia 1924 r. jego zasadniczą część kompetencji przekazało $\mathrm{MSW}^{43}$. Następne poważne zmiany w zakresie kompetencji ministrów spraw wewnętrznych nastąpią dopiero w latach trzydziestych.

${ }^{39}$ R. H a u s ne r, Pierwsze dwudziestolecie..., s. 151. Np. działalność utworzonej w sierpniu 1920 r. Komisji dla Oszczędności Państwowych pod przewodnictwem Stanisława Wojciechowskiego czy powołanego w 1923 r. Nadzwyczajnego Komisarza Oszczędnościowego przy Prezesie Rady Ministrów Stanisława Moskalewskiego.
${ }^{40}$ DzURP, nr 64, poz. 395.
${ }^{41}$ DzURP, nr 106, poz. 774.
42 DzURP, nr 60, poz. 436.
${ }^{43}$ DzURP, nr 9, poz. 86. 
4. 12 maja 1926 r. doszło do zamachu stanu Józefa Piłsudskiego. Dla historyka zasadniczym, jest pytanie o charakter zmian politycznych, które przyniósł ten przewrót. Czy w jego wyniku zmienil się ustrój państwa, czy tylko system polityczny w ramach istniejącego modelu ustrojowego? A może nastąpily wyłącznie modyfikacje $w$ istniejącym systemie politycznym, a jedyną realną zmianą była zmiana ekipy rządzącej? Historiografia dotycząca okresu międzywojennego, choć szereg kwestii jest nadal otwartych, zagadnienia te w znaczny sposób już wyjaśniła. Dość wskazać tu prace: Andrzeja Garlickiego $^{44}$, Antoniego Czubińskiego ${ }^{45}$, Włodzimierza Sulei ${ }^{46}$, Wojciecha Roszkowskiego (Andrzeja Alberta) ${ }^{47}$ czy Krzysztofa Kawalca ${ }^{48}$.

Nie wnikając $w$ bezpośrednie powody i przebieg zamachu stanu z 12 maja 1926 r., skoncentrujemy się na jego konsekwencjach ustrojowych i politycznych. Otóż prawdziwe cele, jakie stawiał sobie Józef Piłsudski czy też jego ścisłe otoczenie, ujawnil szef sztabu wojsk zamachowych gen. Stanisław Burhardt-Bukacki w komunikacie nadanym do władz wojskowych i cywilnych 15 maja 1926 r. o godz. 5.00 rano. Pisał w nim: Pan Prezydent Rzeczypospolitej zrzekl sie wladzy na rzecz marszalka Pilsudskiego i uznal go za jedynie godnego i powolanego do rzqdzenia Polskq. Rzad Witosa zostal rozwiqzany. Marszalek Pilsudski pracuje nad utworzeniem rzqdu, zlożonego $z$ ludzi uczciwych i godnych wladzy. Walk zaprzestano. Oddzialy po uporzqdkowaniu będa odestane do garnizonów. Marszalek Pilsudski nakazuje zachowac spokój $i$ godność wzajemnq wojska ${ }^{49}$. Tak więc Józef Piłsudski próbował działać, jakby był zupełnym zwycięzca, prawdziwym dyktatorem, który nie krępuje się obowiązującym porządkiem prawnym. Sytuacja była inna. $\mathrm{W}$ istocie wojska rządowe rano 15 maja miały już przewage liczebną nad wojskami Marszałka. Na godzinę 11.00 tegoż dnia gen. Kazimierz Ladoś - dowódca wielkiego zgrupowania wojsk rządowych, przygotowywał uderzenie na Warszawę. Józef Piłsudski zdawał sobie $z$ tego sprawę i dążył do kompromisu $z$ nowym, tymczasowym prezydentem Maciejem Ratajem. Los mu sprzyjał, gdyż Rataj również dążył do kompromisu i pacyfikacji za wszelką cenę. W rezultacie M. Rataj działal na korzyść Marszałka: zakazał akcji zaczepnej gen. Ladosiowi, a także innym dowódcom wiernym rządowi - gen. Stanisławowi Szeptyckiemu w Katowicach i gen. Władysławowi Sikorskiemu we Lwowie.

44 A. G a r licki, Przewrót majowy, Warszawa 1979.

45 A. Czubiński, Przewrót majowy, Warszawa 1989.

${ }^{46}$ W. Sule ja, J. Pilsudski, Wrocław 1995.

${ }^{47}$ A. Alb ert [W. Roszkowski], Najnowsza Historia Polski 1914-1993, t. 1: (1914-1945), Warszawa 1995.

${ }^{48}$ K. K a wa lec, Spadkobiercy niepokornych. Dzieje polskiej myśli politycznej 1918-1939, Wroctaw-Warszawa 2000.

49 „Naprzód”, 17 V 1926, nr 112, s. 3. 
Pod koniec dnia 15 maja, o godz. 20.00, po dwóch turach rozmów Piłsudskiego $\mathrm{z}$ Ratajem ogłoszono komunikat dla prasy. W komunikacie tym wyznaczony (już rano) na premiera Kazimierz Bartel ogłosil sklad swojego rządu. Pod względem politycznym rząd ten był bezbarwny. Miał to być gabinet fachowców. Józef Pilsudski został w nim tylko ministrem spraw wojskowych. Zapowiedziano zwolanie Zgromadzenia Narodowego i wybór nowego prezydenta. Stwierdzano: Rząd stoi bezwzglęnie na stanowisku konstytucyjnym. Tak więc pod względem formalnym bylo to znaczne cofnięcie sie w stosunku do nocnego komunikatu Burharta-Bukackiego. Pilsudski nie oglaszal dyktatury, pelniqcy obowiqzki prezydenta Rataj powolal rzqd zgodnie $z$ konstytucja, szef nowego rzqdu glosil, że stoi na gruncie prawa, $i$ zapowiadal wybór prezydenta ${ }^{50}$.

Dzisiaj trudno wyrokować, jakie były prawdziwe intencje Józefa Piłsudskiego. Czy rzeczywiście chciał tylko obalić rząd Wincentego Witosa, nie naruszając dotychczasowego ladu konstytucyjnego, czy też obalając konstytucję, chciał zostać posiadającym pełnię władzy dyktatorem. Faktem jest natomiast, iż ostatecznie, już w pierwszym komunikacie rządu Kazimierza Bartla z 15 maja 1926 r., oficjalnie uznawał dotychczasowy porządek konstytucyjny i system polityczny w państwie. W rezultacie Marszałek dokonał ,rewolucji bez rewolucyjnych konsekwencji”. Wydaje się jednak, iż nawet gdyby chcial „rewolucyjnych konsekwencji”, to nie móglby tego osiągnąć bez wojny domowej. Obóz konstytucyjny broniący legalnych władz Rzeczypospolitej, choć w wyniku zamachu przegrał i musiał oddać władzę, to jednak był na tyle silny, by wymusić na J. Piłsudskim zachowanie dotychczasowego modelu państwa liberalnego, państwa prawa, a nawet pozorów demokracji parlamentarnej.

W rezultacie J. Piłsudski rozpoczął skomplikowaną grę polityczną. Andrzej Friszke pisze: Pilsudski musial sie zdecydować: czy iść z lewica przeciwko prawicy, warstwom posiadajqcym, dzielnicom zachodnim oraz Kościolowi katolickiemu, czy szukać ich poparcia, by zapewnić możliwie duża stabilizacje politycznq $i$ spolecznq kraju. Wybral to drugie rozwiqzanie. Rzady pomajowe staraly sie więc prowadzić umiarkowanq polityke. Nawiazano kontakty $z$ ziemiaństwem, sferami przemyslowymi $i$ mieszczańskimi $i^{51}$. Ostatecznie udało mu się zbudować nowy obóz polityczny, który formy organizacyjne przybrał dopiero w 1928 r. jako Bezpartyjny Blok Współpracy z Rządem Marszalka Józefa Piłsudskiego. Jego podstawe programową stanowiła idea państwowotwórcza (państwowa) w rozumieniu solidarystycznym ${ }^{52}$.

\footnotetext{
so A. Czubiński, Przewrót majowy, s. 224.

5l A. Friszke, op. cit., s. 232.

52 A. Garlick i, Przewrót majowy, s. 266 i n.; A. A 1 bert, Najnowsza historia..., s. 237 i n.
} 
W konsekwencji obóz rządzący, zwany coraz częściej sanacyjnym, umacniał swoje wpływy $\mathrm{w}$ państwie $\mathrm{i}$ społeczeństwie. $\mathrm{Z}$ czasem doprowadzil do zmiany konstytucji ${ }^{53}$. Piłsudczycy pomni oporu, z jakim spotkali się w maju 1926 r., nie zdecydowali się na odrzucenie modelu państwa liberalnego, a jedynie nadali mu państwowotwórczą i solidarystyczną interpretację. Zadekretowali przede wszystkim istniejący już faktycznie wcześniej nowy system polityczny, określany obecnie jako autorytarny lub ograniczonej demokracji. Jego istotą było zasadnicze wzmocnienie w państwie władzy wykonawczej kosztem władzy ustawodawczej. Koncepcja ta zrealizowała się przede wszystkim w konstrukcji jednolitej i niepodzielnej władzy państwowej prezydenta (art. 2, pkt 4) ${ }^{54}$. Zatem poza odrzuceniem zasady rządów demokracji parlamentarnej $z$ omnipotencją sejmu konstytucja utrzymywała $\mathrm{w}$ istocie wszystkie podstawowe zasady państwa liberalnego. Zachowano więc republikańską formę państwa i zasadę konstytucjonalizmu, to jest rządy prawa $w$ państwie. W ramach władzy zwierzchniej prezydenta istniały konstytucyjnie ustanowione organy państwa, takie jak: rząd, sejm, senat, siły zbrojne, sądy i kontrola państwowa. W konsekwencji przyznano prezydentowi pozycję nadrzędną w państwie, ale równocześnie zagwarantowano określony zakres uprawnień ciałom ustawodawczym (sejmowi i senatowi) oraz utrzymano niezawisłość (niezależność) władzy sądowniczej. Utrzymano równość wszystkich obywateli wobec prawa (jednak bez równości w dziedzinie prawa wyborczego $)^{55}$, nietykalność mieszkania, własności prywatnej i opartego na niej systemu gospodarki wolnorynkowej. Zachowano wolności obywatelskie: wolność zrzeszania się (koalicji), myśli, wyznania i sumienia; dalej wolność slowa, prasy i wolność narodowościową. Utrzymano poważnie zmodyfikowaną zasadę odpowiedzialności ministrów przed parlamentem oraz zasadę odpowiedzialności konstytucyjnej ministrów. Cechą tegoż systemu były również takie instytucje polityczno-administracyjne, jak: administracja rządowa, samorząd terytorialny, samorząd gospodarczy i sądownictwo administracyjne ${ }^{56}$.

53 Ustawa Konstytucyjna z dn. 23 IV 1935 r., [w:] M. Adamczyk, S. Pastuszka, Konstytucje...., s. 268 i n.

${ }_{44}$ Ibidem; por. L. M a że wsk i, Prezydencka odmiana systemu parlamentarnego $w$ Konstytucji Kwietniowej, „Studia Prawnicze” 1984, z. 34.

ss Ordynacja wyborcza do Sejmu z dn. 8 VII 1935 r., DzURP, nr 47 poz. 319; Ordynacja wyborcza do Senatu $z$ dn. 8 VII 1935 r., DzURP, nr 47 poz. 320; por. Konstytucje Polski..., s. $202 \mathrm{i} \mathrm{n}$.

${ }^{56}$ G. Górski, Historia administracji, Warszawa 2002, s. 268. Autor pisze: Konstytucja Kwietniowa przez wspólczesnych jej uchwaleniu, a zwlaszcza $w$ okresie powojennym określana byla najróżniejszymi epitetami. Uznawano $j q$ za ,faszystowskq" mówiono, iż stanowila wyraz tendencji ,autorytarnych", że „godzila w polskq demokracje”, że byla zamachem na prawa parlamentu. Z perspektywy czasu widać, jak niesprawiedliwe okazaly sie te zarzuty. Wystarczy porównać jej zapisy z zapisami konstytucji tzw. $V$ Republiki, by dostrzec wiele podobieństw. Użycie takich epitetów pod adresem konstytucji francuskiej uznano by za niczym nie uprawnione. 
5. Wraz ze zmianami politycznymi zachodzącymi po maju 1926 r. następowała częściowa zmiana zadań i celów administracji publicznej. Tak więc - wedhug piłsudczyków - administracja publiczna miała być organizacją stale czynną, która łączyła rządzących z rządzonymi; miala być służbą publiczną. W tej sytuacji szczególnego znaczenia nabierała sprawa zasięgu jej zainteresowania życiem społeczeństwa oraz jej ilościowy $\mathrm{i}$ jakościowy kontakt $\mathrm{z}$ najszerszymi kręgami ludności. To właśnie te kwestie miały rozstrzygać o jej wpływie na rzeczywistość polityczną w państwie. W konsekwencji, senatorowie uważali, iż winna ona być „uspołeczniona i twórcza”. Według Konstytucji kwietniowej, jej naczelnym zadaniem było shużenie Rzeczypospolitej (art. 3); w stosunku do obywateli, do społeczeństwa - miała zapewnieniać życiu społeczeństwa swobodny rozwoj, a gdy dobro powszechne wymaga - nadawać mu kierunek i normować jego warunki (art. 4). Miała strzec, by żadne działanie wewnątrz państwa nie mogło stanąć w sprzeczności $\mathrm{z}$ jego nadrzędnymi celami wyrażonymi w jego prawach. Granica wolności było dobro powszechne. W razie oporu państwo i jego administracja mogły stosować środki przymusu $(\text { art. 10) })^{57}$.

Roman Hausner, dyrektor Gabinetu Ministra w MSW, po 1926 r. pisał, iż na gruncie Konstytucji Marcowej, w ramach trójpodziału władz, istniała władza wykonawcza, której zadaniem było tylko działać celem wykonywania ustaw, z powolaniem sie na upoważnienia ustawowe. Teoretyczna równowaga trzech organów narodu została $w$ praktyce zwichnięta na rzecz omnipotencji sejmu, co $w$ konsekwencji doprowadzilo do plynności $i$ zmienności rzq̨dów i ministrów, a w rezultacie niemożności tworzenia programów na dluższa metę. Stabilizacja ministrów oraz ustalenie programu hierarchii zadań jest jednym $z$ najważniejszych czynników prawidlowego dzialania administracji. Konkludowal więc, że choć w każdym ustroju państwa konstytucyjnego administracja związana jest ustawami, to jednak inaczej działa administracja, która tylko

Majac to na uwadze, konieczne jest podkreślenie, że rozwiqzania przyjęte $w$ Konstytucji Kwietniowej nie tylko tworzyly przeslanki ustrojowe stabilizacji politycznej $w$ kraju, ale również $w$ niczym istotnym nie godzily $w$ demokratyczne instytucje $i$ demokratyczne tradycje polskie. Godzily natomiast w wynaturzenia demokracji, których nie brakowalo w polskim życiu publicznym, zwlaszcza w okresie 1922-1926. Pisze dalej, iż dzięki niej udało się utrzymać ciągłość prawnoustrojową Rzeczypospolitej w latach 1939-1945 oraz utrzymać instytucje prawnoustrojowe II Rzeczypospolitej aż do końca 1990 r. Na zakończenie swego wywodu stwierdza: Jednocześnie o wartości przyjetych $w$ tej Konstytucji rozwiqzań przekonuje fakt, iż gwaltownie kontestujaca jej postanowienia opozycja, w okresie po 1939 r., kiedy mogla, opierajqc się na nich, rzqdzić, zaprzestala ataków na niq $i$ stala siẹ wręcz obroncq określonych instytucji. To jeszcze jeden $z$ dowodów na to, iz wiele $z$ formulowanych oskarżeń pod adresem tego aktu prawnego bylo $w$ glównej mierze efektem nie tyle rzetelnej oceny ustrojowej jego wagi, ile wyrazem politycznej niecheci do obozu politycznego firmujqcego ten dokument.

${ }^{57}$ Ustawa Konstytucyjna z dn. 23 IV 1935 r., [w:] M. Adamczyk, S. Pastuszka, Konstytucje...; por. S. Ca r, B. Podoski, Glówne wytyczne nowej konstytucji, Warszawa 1935. 
wykonuje wladze wykonawczq, a inaczej ta, która przestawi się na dzialania twórcze. Również inaczej działa administracja, która funkcjonuje w ramach systemu podkreślajqcego prawa jednostki wobec państwa, a inaczej ta, która działa $w$ ramach systemu podkreślającego obowiqzki jednostki wobec państwa ${ }^{58}$.

Należy więc stwierdzić, iż odtąd administracja stawała się coraz ważniejszym instrumentem politycznym w ręku obozu pilsudczykowskiego ${ }^{59}$. Konsekwencją tego było upartyjnienie (upolitycznienie) aparatu administracyjnego. Działając „twórczo”, faktycznie stawała się arbitrem w konfliktach spolecznych. Z drugiej jednak strony rządzący dazżyli do „zalegalizowania” tegoż „rozrostu” zadań administracji publicznej, co powodowało, iż jej model mieścił się w konstrukcji państwa prawnego.

Prominentny piłsudczyk i minister spraw wewnętrznych Bronisław Pieracki mówił w sejmie w 1931 r.: ...zachodzi możliwość ścierania sie sprzecznych pradów na tle korzystania $z$ jednych $i$ tych samych swobód obywatelskich. Rząd nie może rozwiklania tego konfliktu pozostawić samopomocy kól zainteresowanych, gdyż prowadziloby to niechybnie do zaklócenia spokoju $w$ państwie. Wladza państwowa musi zatem uzyskać w poszczególnych ustawach dostateczne upowaznienia do przywracania $w$ razie potrzeby stanu równowagi $i$ stanu harmonii. Rząd i administracja winny posiadać takie szczególne uprawnienia, gdyż dobro państwa jest nakazem najwyższym $i w$ imię tego dobra wladza państwowa znalazlszy sie $w$ stanie wyższej konieczności musialaby zastosować środki wiodqce do celu, chociażby nie przewidziane $w$ ustawach [...]. Stojqc na stanowisku konstytucyjnym rzqd chce uniknq̨ć takiej ewentualności $i$ dlatego przewiduje takie upowaznienie wladz, jakie $w$ interesie ochrony wolności wszystkich obywateli uważa za niezbedne. I konkludowal: Nie chcqc $w$ dalszym ciagu takich rozbieżności, uważam, że we wszystkich poczynaniach legislacyjnych, majacych na celu wykonanie zasad konstytucji, trzeba jako punkt wyjścia przyjąc dwie zasady: dobro Państwa jako cel najwyższy; równe obowiazki i prawa dla wszystkich ${ }^{60}$.

6. Ministrowie spraw wewnętrznych i podległa im administracja spraw wewnętrznych formalnie działali nadal w ramach przepisów prawnych ustalonych $w$ pierwszej połowie lat dwudziestych. Zmiany następują przede wszystkim $w$ formach $i$ sposobach ich wpływania na spoleczeństwo, zgodnie

${ }^{58}$ R. H a usner, Pierwsze dwudziestolecie..., s. 28; por. W. Kozyra, W. Sokól, Legitymizacja wladzy politycznej w Drugiej Rzeczypospolitej, [w:] Tradycja $i$ wspólczesność kultury politycznej w Polsce 1918-1990, red. E. Olszewski, Lublin 1991.

${ }^{59}$ Por. W. K ozy r a, Rola struktur administracji państwowej w realizacji myśli politycznej sanacji w latach 1926-1939, [w:] Wizje i realia. Studia nad realizacja mysli politycznej XX wieku, red. W. Paruch, K. Trembicka, Lublin 2002.

${ }^{60}$ Arch. Akt Nowych, Zesp. Min. Spraw Wewn. 1918-1839, Gabinet Ministra, Sekret. Ministra, sygn. 801, s. 119. 
z wyżej zaprezentowanymi zadaniami i celami administracji, ustalanymi przez kierownictwo obozu rządzącego. Dopiero na początku lat trzydziestych następują poważniejsze zmiany w zakresie ustawowych uprawnień ministrów jako kierowników resortu spraw wewnętrznych.

Tak więc rozporządzenie Prezydenta RP z 21 maja 1932 r. znosilo Ministerstwo Robót Publicznych. Część zadań zlikwidowanego ministerstwa przejąl szef resortu spraw wewnętrznych ${ }^{61}$. 21 czerwca tegoż roku Prezydent wydal rozporządzenie, w którym sprawy zdrowia publicznego i kosztów leczenia zostały przekazane Ministrowi Pracy i Opieki Społecznej, z wyjątkiem spraw techniki sanitarnej, które pozostawały nadal w gestii $\mathrm{MSW}^{62}$. Natomiast rozporządzeniem Prezydenta RP z 24 października 1934 r. nadzór nad komunalnymi kasami oszczędnościowymi przekazano Ministrowi Skarbu, który $\mathrm{w}$ tym zakresie mial działać $\mathrm{w}$ porozumieniu z Ministrem Spraw Wewnętrznych $^{63}$. I ostatnia zmiana: dnia 22 lutego 1938 r. sprawy aprowizacyjne wyłączono $\mathrm{z}$ gestii MSW, przenosząc do zadań Ministra Rolnictwa i Reform Rolnych ${ }^{64}$.

Podsumowując ten niepelny przegląd zmian dotyczących zakresu kompetencji Ministra Spraw Wewnętrznych na przestrzeni dwudziestolecia międzywojennego, należy stwierdzić, iż po pierwsze - znaczny odpływ kompetencji $z$ jego pionu nastąpił $w$ latach 1918-1920. W tym okresie z kompetencji MSW ubyły sprawy związane ze służbą zdrowia, budownictwem i odbudową kraju, koncesjonowaniem i zarządem gospodarką wodną, drogami lądowymi, z pocztą i telegrafem, z zakresu weterynarii, statystyki, ubezpieczeń oraz aprowizacji. Natomiast w latach 1921-1923 do resortu spraw wewnętrznych powróciła część zadań będących wcześniej w jego gestii: sprawy zdrowia publicznego, aprowizacyjne i statystyki. Po tym okresie nastąpił prawie dziesięcioletni okres względnej stabilizacji ustawowych uprawnień ministrów spraw wewnętrznych (1923-1932). Ostatnie zmiany zaszły w 1932 r., kiedy to z pionu Ministerstwa Spraw Wewnętrznych ubyły ponownie zagadnienia zdrowia publicznego, a włączono kwestie technicznobudowlane, oraz w 1938 r., kiedy spod kompetencji tegoż ministra zostały wyłączone sprawy aprowizacyjne.

7. Zakres kompetencji administracji spraw wewnętrznych wynikał nie tylko $\mathrm{z}$ ustawodawstwa polskiego, ale również $\mathrm{z}$ obowiązujących nadal $\mathrm{w}$ państwie

${ }^{61}$ DzURP, nr 51, poz. 479.

${ }^{62}$ DzURP z 1932 r., nr 51, poz. 493. Por. R. H a u sner, Zmiany w organizacji wladz naczelnych, „Gazeta Administracji” 1932, nr 18.

${ }^{63}$ DzURP, nr 95, poz. 860.

${ }^{64}$ DzURP, nr 13, poz. 89. 
polskim norm prawnych z czasów zaborców i okupacji ${ }^{65}$. Przykładowo zarządzenie Komisarza Generalnego Ziem Wschodnich z 28 maja 1919 r. postanawiało $\mathrm{w}$ art. 6: Zarzad okregu jest sprawowany $w$ sprawach, przez rozporzadzenie Komisarza Generalnego nie uregulowanych, na podstawie praw, jakie obowiazywaly 5 września 1915 r. z tym, że Komisarz Okregowy przejmuje wszystkie prawa $i$ obowiazki bylego gubernatora ${ }^{66}$. Dostosowanie tej $\mathrm{w}$ istocie wielkiej liczby ustaw obcego pochodzenia do ustawodawstwa polskiego sprawiło w swoim czasie Ministerstwu Spraw Wewnętrznych wiele trudności i dlatego powolano w nim specjalną komórkę: Sekcję Prawno-Opiniodawczą. Z czasem ustawodawstwo to wypierały sukcesywnie przepisy polskie; szczególnie proces ten nasilił się w latach 1926-1928, gdy można było wprowadzać polskie prawo na podstawie pełnomocnictw posiadanych przez prezydenta. W rezultacie, najważniejsze podstawy ustawowe działalności Ministra Spraw Wewnętrznych do 1939 r. zostały uregulowane polskimi przepisami ${ }^{67}$.

7.1. Zakres działania resortu spraw wewnętrznych obejmował obszar całego państwa, wszystkich jego obywateli i przebywających w nim cudzoziemców, bez względu na narodowość, wyznanie i rodzaj zajęcia. Na obszarze państwa polskiego ministrom spraw wewnętrznych podlegała bezpośrednio lub pośrednio gęsta sieć władz i urzędów administracyjnych, a w najważniejszym pionie administracji ogólnej istniało 17 urzędów wojewódzkich, 264 urzędy starościńskie (w tym 241 starostw powiatowych ziemskich i 23 starostwa powiatowe grodzkie).

W pionie policyjnym kierownikom resortu spraw wewnętrznych podlegały: Komenda Główna Policji Państwowej i 15 komend wojewódzkich, Komenda Miasta Stołecznego Warszawy oraz 16 istniejących przy nich urzędów śledczych; następnie 225 komend powiatowych i 17 miejskich (w miastach wydzielonych) oraz ulokowanych przy nich 61 wydziałów śledczych. MSW podlegała również, zorganizowana na innych zasadach niż w pozostałej części kraju, Policja Województwa Śląskiego ${ }^{68}$. Od 1924 r. Ministrowi Spraw Wewnętrznych podlegał, jako formacja wojskowa wykonująca funkcje policyjne w zakresie ochrony granicy wschodniej, Korpus Ochrony Pogranicza na czele $\mathrm{z}$ Komendantem Głównym $\mathrm{KOP}^{69}$.

${ }^{65} \mathrm{Na}$ temat różnych systemów prawnych obowiązujących w Polsce Niepodległej pisali: K. D o bi e l, Przelamywanie granic dzielnicowych w podziale administracyjnym Państwa, "Gazeta Administracji" 1929 , nr 23; W. P a c z osk i, O mocy obowiqzujqcej przepisów wydanych przez niemieckie wladze okupacyjne, „Gazeta Administracji” 1932, ns 9.

${ }^{66}$ Dz. Urz. Zarządu Cywilnego Ziem Wschodnich 1919, poz. 303.

${ }^{67}$ R. H a u s n er, Pierwsze dwudziestolecie..., s. 22-23.

68 Ibidem, s. 55-56.

69 Monitor Polski 1924, nr 61; Historia państwa i prawa Polski 1918-1939, cz. I, red. F. Ryszka, Warszawa 1962, s. 180-181. 
Ministrowie spraw wewnętrznych sprawowali bezpośredni lub pośredni nadzór nad strukturami samorządu terytorialnego, bo funkcje administracji ogólnej w zakresie zleconym spelniało 241 wydziałów powiatowych, 601 zarządów miejskich i 3121 zarządów gmin wiejskich ${ }^{70}$. Oprócz tego szefom tego resortu w latach 1918-1939 podlegało szereg samodzielnych urzędów, organów i zakładów gospodarczych; były to: Główny Urząd Statystyczny (od 1919 r.); Nadzwyczajny Komisarz do Walki z Drożyzną (w latach 1923-1924); Naczelnik Urzędu do Spraw Mniejszości Narodowych z siedzibą w Katowicach (w latach 1922-1937); Zarząd Terenów Przyfrontowych i Etapowych (9 września - 7 listopada 1920 r.); Naczelny Nadzwyczajny Komisarz do Walki z Epidemiami (w latach 1920-1935); Tymczasowy Wydział Samorządowy we Lwowie (1920-1928 r.).

Ministrowi Spraw Wewnętrznych podlegały zakłady i przedsiębiorstwa: Państwowy Zakład Higieny (w latach 1927-1932); Państwowe Zakłady Wodociągowe na Górnym Śląsku (skomercjalizowane w 1928 r.); Państwowe Zakłady Przemysłowo-Zbożowe (w latach 1928-1936); Państwowe Zakłady Badania Żywności i Przedmiotów Użytku (w latach 1928-1934) oraz Przedsiębiorstwo Państwowe „Gazeta Administracji i Policji Państwowej”. Urzędowi MSW podlegały również wojewódzkie sądy administracyjne w Poznaniu i Toruniu ${ }^{71}$.

7.2. Przegląd kompetencji ministrów spraw wewnętrznych wskazuje, że podległa im struktura administracyjna obejmowała szczególnie duży zasięg zadań, o wielkim znaczeniu także dla innych resortów, i warunkowała ich prawidłowe funkcjonowanie. Tak więc na pierwszym miejscu należy wymienić sprawę utrzymania bezpieczeństwa i spokoju publicznego - zagadnienie o kapitalnym znaczeniu nie tylko dla innych resortów, ale dla calego społeczeństwa oraz państwa. Zadaniem ministra było więc analizowanie, a następnie wpływanie na układ stosunków społeczno-politycznych i narodowościowych $w$ państwie, $w$ kierunku pożądanym przez poszczególne ekipy rządzące krajem.

Resort spraw wewnętrznych miał znaczny udział w sprawach przygotowań do obrony państwa, w szczególności zaś - w kwestiach uzupełnienia i zaopatrzenia armii. Mając nadzór nad samorządem terytorialnym i wpływ na jego finanse, oddziaływał pośrednio na sytuację gospodarczą w kraju oraz na współpracę instytucji samorządowych $z$ innymi działami administracji rządowej. Do zagadnień ponadresortowych, które zaliczono do kompetencji ministrów spraw wewnętrznych, należało czuwanie nad organizacją i sprawnością urzędowania władz administracji ogólnej, które obsługiwały bezpo-

\footnotetext{
${ }^{70}$ R. H a usner, Pierwsze dwudziestolecie..., s. $55-56$

${ }^{71}$ Ibidem, s. 52-55.
} 
średnio szereg resortów tzw. zespolonych (w 1938 r. było ich sześć). Władze te współpracowały pośrednio ze wszystkimi resortami administracji państwowej. Szczególnie rozległy był kontakt MSW z terenem, gdyż podlegało mu wiele urzędów administracji lokalnej, policji oraz organów samorządowych. W konsekwencji ministerstwo to posiadało szczególnie dużą liczbę informacji o funkcjonowaniu administracji państwowej w terenie oraz o życiu całego spoleczeństwa. Wykorzystując te właśnie informacje, poszczególne rządy podejmowały strategiczne dla państwa decyzje polityczne ${ }^{72}$.

Tym rozleglym zasięgiem oddziaływania resortu na życie i stosunki w kraju należy tłumaczyć $i$ to, iż $w$ różnych okresach dawano mu zakres obowiązków nie związanych bezpośrednio $\mathrm{z}$ jego domeną działania, na przykład sprawy aprowizacyjne, cenowe, zwalczania drożyzny, nadzór nad stanem sanitarnym kraju itp. Ministrowie spraw wewnętrznych otrzymywali również zadania specjalne; były to $\mathrm{m}$. in.: kierownictwo Zarządu Terenów Przyfrontowych i Etapowych, kierownictwo akcją ewakuacyjną w 1920 r., czy też nadzwyczajne pełnomocnictwa $\mathrm{z}$ ustawy o stanie wyjątkowym. Kierownicy resortu spraw wewnętrznych uczestniczyli w takich gremiach eksperckich i decyzyjnych, jak: Komitet Ekonomiczny Ministrów, Komitet Polityczny Ministrów, Komitet do spraw Gdańska, do spraw Śląska itp. Minister spraw wewnętrznych był członkiem Rady Obrony Państwa w 1920 r. i Komitetu Obrony Rzeczypospolitej. Szefowi Ministerstwa Spraw Wewnętrznych przypadało najczęściej zadanie zastępowania premiera, a w sytuacjach szczególnie trudnych sam premier obejmował ten resort. Zwyczajowo też ministrowie spraw wewnętrznych podpisywali ustawy bezpośrednio po premierze. Wreszcie ministrowie spraw wewnętrznych stali na czele resortu posiadającego jeden $z$ największych budżetów (po wojskowym i oświecenia publicznego ${ }^{73}$.

8. Reasumując, należy stwierdzić, iż II Rzeczpospolita była państwem liberalnym, państwem prawa. W jego ramach funkcjonowały dwa systemy polityczne: system demokracji parlamentarnej funkcjonujący formalnie do 1935 r., choć faktycznie do 1926 r.; następnie system autorytarny, który oficjalnie począl funkcjonować po $1935 \mathrm{r}$. Zadania administracji publicznej i jej organizacja wynikaly więc z pryncypiów ustrojowych oraz z bieżących potrzeb spolecznych. Część zadań realizowali ministrowie spraw wewnętrznych przez podległą im strukturę administracyjną. Ich uprawnienia - najogólniej rzecz ujmując - można by podzielić na dwa wzajemnie przenikające się działy czy obszary. Pierwszy z nich - to szeroko rozumiany dział polityczno-

${ }^{n}$ D. Ma le c, J. M a lec, Historia administracji nowożytnej..., s. 154 i n.

${ }^{73}$ R. H a u s ner Pierwsze dwudziestolecie..., s. 26-27. 
-administracyjny, którego domeną bylo ustalanie głównych kierunków polityki administracyjnej resortu wynikających $\mathrm{z}$ wyżej zaprezentowanych pryncypiów. Drugi - to obszar administracyjny sensu stricte. W jego ramach realizowano założenia polityki administracyjnej resortu w konkretnych kompleksach fachowo-administracyjnych, takich jak: sprawy bezpieczeństwa i porządku publicznego, administracji samorządowej, sprawy stanu cywilnego i ruchu ludności, zabudowy osiedli, techniki sanitarnej, cenzury prasowej czy filmowej itp. 